補正法について

\title{
Correction methods; General remarks
}

\author{
由 井 俊 三 (Shunzo Yui)*
}

\section{1. 検量線による補正}

EPMA による定量分析法は, ある管理された条件の下で, 試料と標準試料を加速 電子で励起させ, 発生した特性 X 線の強度比から試料の化学組成を求める方法であ る。強度比の測定方法, 標準試料についてはすでに述べられているので,ここでは強 度比の正しい值が得られたものとしてその処理法について述べる。

未知試料に近い組成の標準試料が得られる場合には, 検量線によってまたは単に強 度比に標準試料の組成を乗ずることによって, 容易に精度の高い分析結果を得ること も可能である ${ }^{21)}$ 。それゆえ, 組成に共通性のある多数の試料を分析する場合には, ま ずそのための標準試料を準備することが望ましい。

\section{2. 計算による補正}

試料の組成に近い，理想的な標準試料が得られない場合でも，酸化鉣物・珪酸塩鉱 物に対しては単純な酸化物, 硫化鈗物に対しては単純な硫化物を標準試料として用 い, 得られた強度比に基ついて“補正計算”を行ない，かなりまで正確な分析結果を 得る場合も多い。現在釷物学の分野で広く行なわれている補正計算は 2 つに大別され る。その 1 つは経験的な補正係数を用いる方法であり, 他は電子の衝突から X 線の発 生・強度の湘定にいたる過程で起ると考えられる物理現象について, 近似的計算式を 推定し、その組合せから組成を求める方法である。

\section{3. 経験的な補正係数を用いる方法}

この方法は Bence and Albee1)によって珪酸塩鉱物の分析に適用された方法であ る。多くの, 酸化物, 珪酸塩の 2 成分系において, 酸化物の重量濃度 C と, その酸 化物を作る元素の特性 X 線のその端成分に対する強度比 $\mathrm{K}$ との間に次の様な関係の あることが認められている。

* 秋田大学鉱山学部 


$$
\begin{array}{r}
\text { 補正法について } \\
\frac{1-\mathrm{K}^{\mathrm{A}}{ }_{\mathrm{AB}}}{\mathrm{K}^{\mathrm{A}}{ }_{\mathrm{AB}}}=a^{A}{ }_{\mathrm{AB}} \frac{1-\mathrm{C}_{\mathrm{AB}}}{\mathrm{C}^{A}{ }_{\mathrm{AB}}}
\end{array}
$$$$
-67-
$$

ここで $\mathrm{C}^{\mathrm{A}} \mathrm{AB}$ は $\mathrm{AO}-\mathrm{BO}$ の 2 成分系における $\mathrm{AO}$ の重量濃度, $\mathrm{K}^{\mathrm{A}}{ }_{\mathrm{AB}}$ はバックグ ラウンドと数え落としの補正を施した $\mathrm{A}$ の特性 $\mathrm{X}$ 線の端成分 $\mathrm{AO}$ に対する強度比で ある。 $\boldsymbol{\alpha}^{\mathrm{A}} \mathrm{AB}$ は $\mathrm{AO}-\mathrm{BO}$ の組合せ・加速電圧・X 線取出角によってきまり，組成によ らない常数である。多成分系の補正俰数は $\beta$ で表わされている。

$$
\beta^{\mathrm{A}}{ }_{\mathrm{ABC} \cdots n}=\frac{\mathrm{C}^{\mathrm{A}} \mathrm{ABC} \cdots n}{\mathrm{~K}^{\mathrm{A}} \mathrm{ABC} \cdots n}
$$

この $\beta$ 保数は多くの場合, 実用上十分な精度で $\boldsymbol{\alpha}$ 係数の各酸化物重量濃度の重みつ き平均として与えられる。未知試料の分析に際しては各酸化物の重量濃度が未知数で あるので，Kを $\mathrm{C}$ の第 1 近似として $\boldsymbol{\beta}$ を求め， $\mathrm{K}$ と $\boldsymbol{\beta}$ から $\mathrm{C}$ を求める計算を綝 返し、収敛した值を組成の推定値とする。

$\boldsymbol{\alpha}$ 係数は, まず Bence and Albee ${ }^{1)}$ にっって 10 特性 X 線と11酸化物の組合せにつ $い て$, 加速電圧 $15 \mathrm{kV}$, 取出角 $52.5^{\circ}$ の場合について, 一部実測, 一部計算によって 求められた。この値は, Nakamura and Kushiro²)よって取出角 $40^{\circ}$ の場合に換算さ れた。さらに Albee and Ray3)は, 後述する個々の物理現象に基づく補正法を逆に用 い, 多数の仮想的な酸化物 2 成分采について，その計算強度比から $\boldsymbol{\alpha}$ 係数を求めた。 計算による $\boldsymbol{\alpha}$ 係数は種々の加速電圧・取出角について容易に求められる。

この大別して 2 組の $\alpha$ 係数のいずれがより正しい値を与えるかについては種々の 意見があり，両者の平均を採用している人もある。田崎・猪俣4は Nakamura and Kushiro2)を採用している。

この方法の利点は，計算の容易であること，実測に基づいて $\boldsymbol{\alpha}$ を決定した場合に はあらゆる要因について補正していること等である。この方法を硫化物に適用する試 みは別章で（p. 85）取扱われている。他方この方法の限界は元素の組合せによって は， $\boldsymbol{\alpha}$ が組成によって変化することである。そのため，簡便さを苦干犠牲にして，a を組成の関数として表わし，この方法の適用範囲を拡げる試みも行われている。

\section{ZAF 補 正 法}

EPMA 測定の際の一連の物理現象のおもなるのは, 入射電子の試料表面での反射, 試料内への浸透, 浸透した電子による試料を構成する原子の励起, $\mathrm{X}$ 線の発生, $\mathrm{X}$ 線 の試料による吸収， X 線による 2 次 X 線の発生，その試料による吸収等々である。 $\mathrm{X}$ 線の発生までの諸現象はおるに試料構成原子の原子番号によるので，まとめて原子 番号効果と呼ばれ，てれに関連して強度比に加える補正を原子番号補正と呼ぶてとが 多い。X 線の吸収，2 次 $\mathrm{X}$ 線に関係した補正をそれぞれ吸収補正，螢光補正と呼ぶ。 
この 3 種の補正を総称して ZAF 補正と略称している。螢光補正は特性 X 線による ものと，連続 X 線によるものとにわけられる。原子番号補正と吸収補正は 1 次 X 線 に関係したものとして一括して取扱われることもある。

この ZAF 補正法を釷物学関係の雑誌で総合的に論したのは Sweatman and Long) である。彼等の表現は下記の通りである。添字 0 は標菹試料、1は未知試料を示す。

$$
\begin{aligned}
& \mathrm{C}_{\text {true }}=\mathrm{C}_{\text {measured }} \times \frac{\mathrm{R}_{0}}{\mathrm{R}_{1}} \frac{\mathrm{S}_{1}}{\mathrm{~S}_{0}} \times \frac{f(x)_{0}}{f(x)_{1}} \times \frac{\left(1+\gamma_{0}\right)}{\left(1+\gamma_{1}\right)} \times \frac{1+\psi_{0}}{1+\psi_{1}} \\
& \text { 原子番号 吸収烙光補正 螢光補正 } \\
& \text { 補需補正 (特性X線) (白色X線) }
\end{aligned}
$$

この式に含まれる各要素につ いて，それを表す近似式，式に 含まれる各種の常数の値として。 研究者によって異ったものが提 案されている。それらはその計 算ステップ（第 1 図）と共に Heinrich ${ }^{6)}$ によって吟味されて いる。計算には，現実問題とし て電算機が不可欠でプログラム としては 150 種以上存在するだ ろらと云われている7。

Beaman and Isasi $\left.{ }^{7}\right) 1970$ 年 に入手出来た補正計算電算機プ ログラム 40 を吟味している。 ZAF 補正計算の 36 種のプログ ラムのらち, 彼等の推せんして いる 4 種を含めて多くのプログ ラムが，原子番号補正には Duncumb and Reed ${ }^{10)}$, 吸収

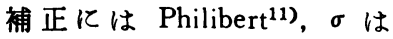
Duncumb and Shield ${ }^{12)}$ 又は Heinrich ${ }^{13)}$ ，質量吸収係数は Heinrich ${ }^{14)}$ )計算又(表)，特性 X線による螢光補正にはReed ${ }^{15}$ ) のものを用い，連続 X線による 螢光補正を無視している。次章

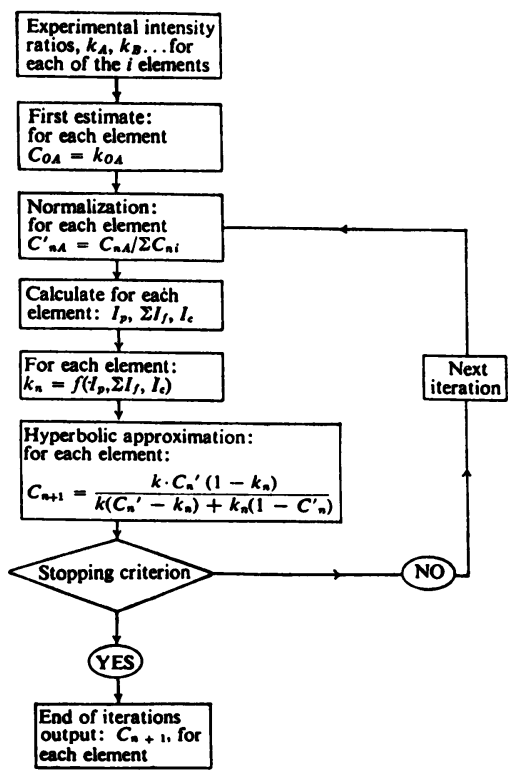

Figure 1. Hyperbolic approximation iteration. Each step is performed in parallel for all elements present in the specimen

第1図双曲線近似を用いた繰返し計算。各ステッ フは必要な全元素について平行して行われる。 $\left(H_{e i n r i c h}^{61}\right) \quad I_{p}: 1$ 次 $\mathrm{X}$ 線に関する要因, $\mathrm{I}_{f}$ : 特性 $\mathrm{X}$ 線による螢光励起, $\mathrm{I}_{t}$ : 連続 $\mathrm{X}$ 線による䖝光励起, $\mathrm{K}_{n}: \mathrm{n}$ 回目の計算強度比, $\mathrm{C}$ : 重量濃度 
第 1 表 各種の補正計算ブログラムによる計算テスト

\begin{tabular}{|c|c|c|c|c|c|c|c|c|}
\hline \multirow{2}{*}{\multicolumn{2}{|c|}{$\begin{array}{l}\text { Alloy Systems } \\
\text { Elements }\end{array}$}} & \multicolumn{2}{|c|}{$\mathrm{Ti}-\mathrm{Nb}$} & \multicolumn{3}{|c|}{ Cr-Co-Mo } & \multicolumn{2}{|c|}{ Fe-Ni } \\
\hline & & $\mathrm{Ti}$ & $\mathrm{Nb}$ & $\mathrm{Cr}$ & Co & Mo & $\mathrm{Fe}$ & Ni \\
\hline \multicolumn{2}{|c|}{$\begin{array}{l}\text { True Chemical } \\
\text { Concentration }\end{array}$} & 35.0 & 65.0 & 9.9 & 80.6 & 9.4 & 43.6 & 56.4 \\
\hline & & \multicolumn{7}{|c|}{ Calculated Wt. \& } \\
\hline $\begin{array}{l}\text { Mean } \\
1 \sigma \\
\sigma / c\end{array}$ & $\star 1$ & $\begin{array}{r}34.9 \\
0.9 \\
2.6\end{array}$ & $\begin{array}{r}65.0 \\
1.0 \\
1.5\end{array}$ & $\begin{array}{r}10.3 \\
0.4 \\
3.8\end{array}$ & $\begin{array}{r}80.7 \\
0.5 \\
0.6\end{array}$ & $\begin{array}{l}9.8 \\
0.3 \\
3.1\end{array}$ & $\begin{array}{r}44.8 \\
0.6 \\
1.5\end{array}$ & $\begin{array}{r}56.1 \\
0.6 \\
1.1\end{array}$ \\
\hline $\begin{array}{l}\text { Mean } \\
1 \sigma \\
\sigma / c\end{array}$ & *2 & $\begin{array}{r}34.8 \\
0.3 \\
0.9\end{array}$ & $\begin{array}{r}65.3 \\
0.2 \\
0.3\end{array}$ & $\begin{array}{r}10.3 \\
0.2 \\
1.9\end{array}$ & $\begin{array}{r}80.8 \\
0.2 \\
0.2\end{array}$ & $\begin{array}{l}9.9 \\
0.2 \\
2.0\end{array}$ & $\begin{array}{r}45.0 \\
0.3 \\
0.7\end{array}$ & $\begin{array}{r}56.0 \\
0.4 \\
0.7\end{array}$ \\
\hline \multicolumn{2}{|c|}{ Shoji } & 34.6 & 65.3 & 10.1 & 80.6 & 9.7 & 45.0 & 55.9 \\
\hline
\end{tabular}

Beaman and Isasi' ${ }^{7)}$ 第 11 表をまとめ, それに正路のブログラム による結果を加えたもの。

*1 すべてのプログラムによる結果のまとめ。

*2 p68 下から 9〜4行に示した方式による 13 ブログラムによる結 果のまとめ。

に揭げた正路のプログラムも同様である。連続 X 線による 螢光補正 (Springer8) または Hénoc9) による)を考慮しているのは 36 種のうち 7 種のみである。各種プロ グラムによる補正計算テスト結果を正路による結果と共に第 1 表に示す。

連続 X 線による螢光励起は一般に影響が小さく，かつその補正計算が複雑である ため, 上記の様に省略されることが多いが，Reed ${ }^{16)}$ によれば，Ka 線を用いて原子 番号 $\mathrm{Z}<18(\mathrm{Ar}) ， \mathrm{~L} a$ 線を用いて $\mathrm{Z}<40(\mathrm{Mo})$ の元素を分析する時以外は無視出来 るほど小さいとは限らない。

補正計算の際の誤差は, 近似式, 各種常数, 計算の際の簡略化等から生ずるが, Heinrich6) はそれらの誤差を最小に留めた新プログラムの開発を報告し, 丸野重雄の 談話によれば, Henke ${ }^{17)}$ が質量吸収係数の新しい值を報告している。

EPMA による化学分析の正確さについては Heinrich6)等によっても吟味されてい るが，補正計算に起因する誤差が，測定の精度・標準試料の品質による誤差と比較し て、とくに大きいことはないようである。

$$
\text { 文献 }
$$

文献は次の論文と重複するものが多いので p. 73 亿一括して示す。 